\section{Krzysztof Unilowski}

Uniwersytet Śląski

w Katowicach

\title{
Krytyka po literaturze
}

\section{Abstract \\ Literary Criticism after Literature}

The article is focused on literary criticism within the post-literary formation. The author describes it in the historical and cultural perspective of institutional changes and the consequences of different ways of defining literature and its functions. The term "post-literary" is used here to name the present condition of literature incorporated into cyberculture. This inclusion results not only in traditional readership ceasing to function as a privileged reading practice, but above all in dehierarchisation, heteronomisation, deprofessionalisation and egalitarianisation of literature (the changeability of sender and recipient roles; ease of publishing; change of text intelligibility and dispossession of literature from an earmarked discursive space). Therefore, the circulation and the very status of literary criticism has also evolved. The author shows that the literary criticism that has emerged from the experience of the new media is not only entertainment oriented and that it does not have to be non-intellectual. He gives a detailed description of the key differences between traditional and new criticism.

Słowa kluczowe: krytyka literacka, postliteratura, nowe media, cyberkultura

Keywords: literary critisism, post-literary formation, new media, cyberculture 
Najnowszy raport Biblioteki Narodowej o stanie czytelnictwa w Polsce, którego wstępna wersja została ogłoszona pod koniec marca $2019 \mathrm{roku}^{1}$, pokazuje, że po zapaści z początku pierwszej dekady nowego wieku, kiedy liczba osób przyznających się do nieczytania raptownie wzrosła, mamy obecnie do czynienia ze względnie stabilną sytuacją. Od dziesięciu lat odsetek czytających wynosi mniej więcej 38 procent ogółu dorosłych Polaków. Tak przynajmniej wynika z deklaracji ankietowanej próby, bo przecież - o czym trzeba pamiętać - raporty Biblioteki Narodowej operują danymi, które zebrano dzięki badaniom sondażowym opinii publicznej. A skoro tak, to możemy przyjąć, że również odnotowany na początku XXI wieku wyraźny spadek poziomu zadeklarowanego czytelnictwa wynikał tyleż z rzeczywistej zmiany praktyk kulturowych (na przełomie lat dziewięćdziesiątych i dwutysięcznych gospodarstwa domowe uzyskały szerokopasmowy dostęp do internetu), co ze zmiany świadomości - nieczytanie książek przestało uchodzić za coś wstydliwego!

Dyskusja po opublikowaniu tegorocznego raportu, która przetoczyła się w mediach (tradycyjnych i cyfrowych), dopisała tu ciekawą pointę. Oto wśród powtarzających się od lat narzekań na niechęć Polaków do książek pojawił się nowy ton. Przykładem niech będzie post (to znak czasu) artystki estradowej i pisarki, Natalii Fiedorczuk-Cieślak, zamieszczony pierwotnie na jej profilu fejsbukowym:

Do współsióstr i współbraci lamentujących nad tym zatrważająco wysokim odsetkiem społeczeństwa, które nie ma w domu ani jednej książki: dajcie spokój. [...] Fetyszyzowanie nowego, średnioklasowego intelektualizmu, opartego na zawartości biblioteki jest słabe. Nie każdy ma hajs na książki. Nie każdego książki nauczą krytycznego myślenia. Nie każdy ma zdolności i chęci poznawcze, by pochłaniać wartościowe tomy. Nie każdy z tych kupujących, gromadzących, selfikujących się z książkami czyta lektury wartościowe, niebędące jedynie rozrywką, zabiciem czasu².

Rzeczywiście, konserwatywny charakter głównego nurtu współczesnej polskiej kultury wyraża się między innymi przez fetyszyzowanie czytelnictwa książek. Stąd ogromne znaczenie przypisywane wskaźnikom liczbowym. Nawiązując do głośnych kampanii, mających jakoby na celu promocję literatury i czytelnictwa, można powiedzieć, że lektura najwyraźniej stała się czynnością akcyjną, którą uprawiamy po to, aby wyniki krajowe zbliżyć do poziomu

1 I. Koryś, R. Chymkowski, Stan czytelnictwa w Polsce w 2018 roku. Wstępne wyniki, dokument elektroniczny na stronie internetowej Biblioteki Narodowej, https://www.bn.org. pl/download/document/1553593649.pdf [dostęp: 21.06.2019].

2 Cyt. za artykułem 10 opinii o czytelnictwie w Polsce, którymi zablyśniesz w towarzystwie, 26.03.2019, blog czytelniczy.pl, http://czytelniczy.pl/czytelnictwo-w-polsce-2019/ [dostęp: 21.06.2019]. 
europejskiego! Podnoszona zaś do znudzenia przez media kwestia domniemanego kryzysu służy unikaniu trudniejszych kwestii: co robimy z książkami? Do czego nam służą? I najważniejsze: jakie nowe praktyki kulturowe pojawily się obok tradycyjnej lektury?

Do niedawna czytanie książek, rozumiane jako uczestnictwo w kulturze literackiej, pełniło funkcję jednej z dystynkcji między klasą średnią a klasą ludową. W społeczeństwach nowoczesnych kluczowa rola mieszczaństwa, warstwy urzędniczej czy inteligencji przejawiała się w ten sposób, że wzorce kulturowe wypracowane przez te grupy zyskiwały status norm ogólnospołecznych. Jak wiadomo, współczesne procesy makroekonomiczne wraz z następstwami rozwoju nowych technologii medialnych zachwiały pozycją klasy średniej, zbliżając jej habitus do poziomu życia klasy ludowej. W rezultacie tradycyjne czytelnictwo przestało pełnić funkcję uprzywilejowanej praktyki kulturowej, acz na razie zachowuje przynajmniej część dawnego prestiżu. Obcowanie z książką - bez względu na jej charakter i styl naszej lektury - pozwala zyskać poczucie, że wykraczamy poza statystyczną przeciętność. $Z$ drugiej jednak strony postępujące zacieranie się granic między literaturą artystyczną oraz innymi, mniej nobliwymi odmianami piśmiennictwa (pisarstwo popularne, gatunki dziennikarskie, poradniki itd.), również rewolucja technologiczna w biznesie wydawniczym (e-booki, self-publishing, malejące koszty druku) - wszystko to sprawia, że prestiż zyskany dzięki lekturze książek (zwłaszcza literackich) nie może być duży. W ten sposób czytanie przemieszcza się do rzędu praktyk hobbystycznych.

Przytoczona wyżej wypowiedź Fiedorczuk-Cieślak wydaje się symptomatyczna $\mathrm{z}$ innego jeszcze powodu: otóż sytuacja pola literackiego zmieniła się tak dalece, że - jak się okazało - na uwagę zasłużył głos, który podał w wątpliwość uprzywilejowany status tegoż pola ${ }^{3}$. Jednym ze skutków społeczno-kulturowej fetyszyzacji czytania jest petryfikacja dominującego sposobu rozumienia literatury. W takiej sytuacji, czytając dany tekst jako artystyczny, gotowi jesteśmy szukać w nim tego, co należy do utrwalonego społecznie kodu literackiego: uniwersalnych problemów egzystencjalnych, wrażliwości moralnej, nawiązań do kulturowego kanonu, estetyczno-stylistycznej elegancji itd., itp.

3 Post Fiedorczuk-Cieślak niemal natychmiast wykroczył poza ramy fejsbukowej „bańki”. Polemicznie odniósł się do niego Grzegorz Wysocki na łamach „Gazety Wyborczej” (zob. Martwisz się, że Polacy nie czytaja ksiażek? To znaczy, że jesteś snobem. Absurdalna awantura o klasizm czytajacych, Wyborcza.pl, 30.03 .2019 http://wyborcza. pl/7,75517,24597816,martwisz-sie-o-kiepskie-wyniki-czytelnictwa-jestes-snobem.html [dostęp: 21.06.2019], z kolei wsparcia udzielił autorce między innymi Jakub Szestowicki z portalu Noizz.pl, Biadoląc, że „28\% Polaków i Polek nie ma w domu ksiązki” prosicie się o śmiech lub maść na ból dupy, https://noizz.pl/opinie/dzien-ksiazki-2019-polacy-nieczytaja-jak-promowac-ksiazki-zeby-to-mialo-sens/fjgfjzn [dostęp: 21.06.2019]. 
Zapominamy przy tym, że literatura, która nie pyta i nie kwestionuje siebie samej, funkcjonuje jako produkt zastanego systemu kulturowego i służy potwierdzaniu dominującej ideologii.

Dlatego kwestionowanie obowiązujących reguł ma swoją wartość. Jakkolwiek silne byłyby nasze kulturowe nawyki i jakkolwiek mocno usiłowalibyśmy przy nich trwać, to jednak nowe media na zawsze zmieniły nasz stosunek do literatury i sposób jej postrzegania. Negując wartość podziału na tych, którzy czytają/posiadają książki, i tych, którzy ich nie czytają i nie posiadają, Fiedorczuk-Cieślak każe szukać dystynkcji zupełnie gdzie indziej.

Nie dość powtarzania, że instytucja literatury jest stosunkowo świeżej daty i że narodziła się dopiero w wieku XVIII, wraz ze wzrostem politycznej i kulturowej roli mieszczaństwa, pojawieniem się obywatelskiej sfery publicznej ${ }^{4}$, stopniowymi postępami alfabetyzacji (już w roku 1717 król pruski Fryderyk Wilhelm I ogłosił edykt o powszechnym obowiązku szkolnym, jakkolwiek jeszcze długo takie prawo miało pozostać wyłącznie na papierze), rozwojem prasy, która z początkiem wieku XIX stała się pierwszym medium komunikacji masowej, wreszcie - wprowadzeniem pojęcia autora i autorstwa jako kategorii prawnych ${ }^{5}$. Genetyczny i genealogiczny związek literatury z czasopiśmiennictwem zaznaczył się między innymi w ten sposób, że na pierwszy plan wysunęły się nowe formy gatunkowe (przede wszystkim powieść), nieobecne w klasycznych poetykach, i jakkolwiek kategoria ta szybko znalazła zastosowanie również w odniesieniu do pisarstwa artystycznego wcześniejszych epok, to łatwo zauważyć, że co najmniej przez całe XIX stulecie utrzymywało się wyraźne napięcie między pojęciami poezji (rozumianej jako sztuka) i literatury (rozumianej jako działalność komercyjna, dostarczanie rozrywki itp.). Jeszcze oświeceniowy klasycyzm traktował lirykę - w ślad za starożytnymi jako wypowiedź „mową wiązaną” na temat właściwy z punktu widzenia reguł konkretnego gatunku. Dlatego też pojmowana w ten sposób poezja nie była odseparowana od innych form piśmiennictwa i mogła występować jako traktat, podręcznik, modlitewnik, pisarstwo parenetyczne (dostarczające wzorów osobowych i moralnych), satyra obyczajowo-społeczna, publicystyka polityczna, itd. Właśnie dlatego, że na progu nowoczesności wszystkie te funkcje zaczęła przejmować prasa, w ramach rewolucji romantycznej liryka została

4 Zob. J. Habermas, Strukturalne przeobrażenia sfery publicznej, przeł. W. Lipnik, M. Łukasiewicz, red. M. Czyżewski, Warszawa 2007.

5 Zob. M. Woodmansee, The Author, Art, and The Market. Rereading the History of Aesthetics, New York 1994. 
zdefiniowana na nowo, jako wypowiedź nienormatywna, idiomatyczna, a zarazem jako metoda całościowego poznania i świadectwo pisarskiego geniuszu. Co ciekawe, z punktu widzenia romantyków funkcje użytkowe (i komercyjne) zostały przypisane... literaturze jako nowoczesnej (i zdegenerowanej) formie dawnego piśmiennictwa.

Można podejrzewać, że ostateczne pojednanie nowoczesnej (poromantycznej) poezji z literaturą dokonało się nie bez udziału akademików. Zdaniem Josepha Hillisa Millera:

Być może przesadą jest twierdzenie, iż współczesne wyobrażenie literatury zostało stworzone przez uniwersytet badawczy i przez przygotowujące do niego szkolnictwo niższego szczebla. [...] Nasze rozumienie literatury zostało jednakże w dużym stopniu określone przez pisarzy wykształconych na uniwersytetach. [...] Literatura miała kształcić obywateli, dając im wiedzę na temat tego, co - jak to ujmował [Matthew Arnold - dop. K.U.] - „najlepszego poznano i pomyślano na świecie”. Owo „najlepsze” było, jego zdaniem, pieczołowicie skryte w kanonicznych dziełach Zachodu - od Homera i Biblii po Goethego i Wordswortha. Większość ludzi w dalszym ciągu po raz pierwszy dowiaduje się, że istnieje coś takiego jak literatura od swoich szkolnych nauczycieli ${ }^{6}$.

Synteza obu pojęć polegała na tym, że literatura uchodziła za uprzywilejowane narzędzie poznawcze (to motyw romantyczny), a jednocześnie traktowana była utylitarnie, jako instrument wychowania. Zauważmy jednak, że w tym ujęciu literatura, owszem, pełni funkcje użytkowe, ale jednocześnie zachowuje status wypowiedzi zasadniczo innorodnej, należącej do osobnej klasy, różniącej się zasadniczo od wszystkich pozostałych odmian piśmiennictwa. Z a istotę literatury uznaję właśnie ów motyw ekskluzywny, mianowicie - przekonanie, że jest ona czymś, co w sposób zasadniczy odbiega

6 J.H. Miller, O literaturze, przeł. K. Hoffmann, Poznań 2014, s. 15-16. Por. uwagi Macieja Maryla: „Potrzeba wyróżnienia literatury - jako zbioru tekstów istotnych dla danej społeczności - spośród rozmaitych form piśmiennictwa rodzi się dopiero w początkach w. XIX, w okresie gdy nauka o literaturze konstytuuje się na uniwersytetach, pełniąc narodotwórczą rolę. Oczywiście, już wcześniej istniały teksty uznawane dziś za literackie (np. charakteryzujące się użyciem specyficznych konwencji), ale powstawały one w innym kontekście społecznym i kulturowym, w którym nie było potrzeby odróżniania literatury od nieliteratury" (M. Maryl, Technologie literatury. Wpływ nośnika na formę i funkcje przekazu literackiego, „Pamiętnik Literacki” 2010, nr 2, s. 160). Jednocześnie autor, obok historycznego i technologicznego sposobu rozumienia literatury, wprowadza również odmienną, bardziej esencjalistyczną i transmedialną kategorię „literatury” (dla odróżnienia termin w tym drugim ujęciu Maryl zapisuje w cudzysłowie). Zupełnie niepotrzebnie. W moim przekonaniu tendencja dla rozszerzania zakresu terminu na wybrane dzieła i sektory piśmiennictwa wcześniejszych stuleci wynikała wyłącznie z interpretacji dokonywanej ex post, a więc przez pryzmat literatury jako kluczowego pojęcia dla całej nowoczesnej formacji kulturowej. 
od wszystkich nieliterackich form wypowiedzi, przy czym ta domniemana różnica jest zarazem podstawą jej uprzywilejowania. Mniejsza jak rozumieć tę istotną dyferencję i czy identyfikować ją z dominacją funkcji poetyckiej, fikcjonalnym charakterem tekstu, nieweryfikowalnym statusem zawartych w tekście twierdzeń, (nieskończenie) złożoną modalnością... Jakkolwiek ją definiować, za sprawą tej rozmaicie opisywanej przez teoretyków różnicy literatura zyskuje autonomię i zostaje usytuowana na pozycji krytycznej metarefleksji całej naszej épistéme, albowiem przypisujemy jej zdolność do przedstawiania i analizowania wszelkich innych form wypowiedzi (naukowych, publicystycznych, politycznych, prywatnych, „gatunków” mowy potocznej itd.), tym bardziej że ona sama nie podlega redukcji do żadnej z tych form. $Z$ drugiej strony, jej odrębność i odmienność czynią jej status problematycznym z punktu widzenia komunikacyjnej pragmatyki. Bez względu bowiem na to, jakie (krytyczne, głębokie, doniosłe) wnioski wyciągnęlibyśmy z lektury tekstu literackiego, łatwo je zlekceważyć odpowiadając, że to wszystko wyłącznie... literatura.

Oczywiście, z nowoczesnej perspektywy nie tylko dawna poezja, ale też romanse czy satyry menippejskie (starożytne i nowożytne), dają wszelkie podstawy, by je uznać za dzieła literackie. Pamiętajmy jednak, że chodzi o utwory, które powstawały w ramach systemów kultury, gdzie granica między wypowiedzią fikcjonalną i niefikcjonalną nie była restrykcyjna i miała charakter przechodni. Stąd obecność na przykład elementów fikcyjnych w dziełach dawnych filozofów lub dziejopisarzy. Z drugiej strony, czytelnicy Listów heter Alkifrona (II-III w. n.e.) z pewnością mieli świadomość, że obcują z tekstami fikcjonalnymi, które wyłącznie parodiują konwencję epistolograficzną, przedstawiając prześmiewczą wizję przeszłości. Nie znaczy to jednak, że dzieło Alkifrona (podobnie jak Satyry Lukiana, Gargantua i Pantagruel Françoisa Rabelais'go) już prymarnie funkcjonowało na prawach dzieła, któremu przysługiwałaby estetyczna autonomia pojmowana na sposób nowoczesny. Jego rolą była intelektualna gra z kanoniczną wersją przeszłości i tradycją kulturową, wszelkie zaś estetyczne aspekty tekstu były sprawą dalszego planu. Rzecz jasna, również pisarzom nowoczesnym wcale często zdarzało się podejmować podobną grę, ale też czynili tak nie w obrębie zróżnicowanego obszaru piśmiennictwa, lecz we własnej, wydzielonej, literackiej przestrzeni dyskursywnej.

Zasadniczą zmianą, którą obserwujemy współcześnie, jest postępująca dehierarchizacja i heteronomizacja literatury. Wraz z nią coraz bardziej problematyczna okazuje się uprzywilejowana pozycja, zyskiwana przez literaturę w ramach nowoczesnej kultury druku. Najbardziej uchwytnym przejawem tego procesu jest marginalizacja sztuki słowa $\mathrm{w}$ środkach masowego przekazu. Nie musi to wcale oznaczać, że z dnia na dzień przestaliśmy się interesować powieściami czy tomami wierszy, że porzuciliśmy lekturę dla filmu, gier wideo czy choćby internetowych mediów społecznościowych. Ze wspomnia- 
nych na wstępie badań czytelnictwa na zlecenie Biblioteki Narodowej wynika, że spadek aktywności w tym zakresie jest faktem, rzecz jednak w tym, że literatura - nawet jeśli ją czytamy - nie uchodzi już za tak ważny sektor kultury i życia społecznego jak wcześniej. Oczywiście, kanon literatury narodowej pełni nadal istotną rolę w edukacji szkolnej, ale i tu bywa uważany za coraz bardziej niewydolne narzędzie konstruowania wspólnoty. Studia filologiczne wciąż są chętnie podejmowane, ale ponieważ zapewniają niewielki prestiż, to niekoniecznie bywają kierunkiem pierwszego wyboru. Zresztą w całym świecie zachodnim same uniwersytety podlegają zmianom w neoliberalnym duchu, zatem w coraz mniejszym stopniu przypominają instytucje, gdzie jednym z kluczowych zadań był humanistyczny Bildung.

Najistotniejsze jednak, że głównym instrumentem uczestnictwa w kulturze stały się współcześnie media elektroniczne. Dokonująca się za ich sprawą konwergencja ${ }^{7}$ przyczyniła się między innymi do tego, że pewne właściwości uznawane za typowe dla utworów literackich - poetyckość, narracyjność, fikcjonalność, autorefleksyjność - okazały się ważne także z punktu widzenia tekstów o innym charakterze, sama zaś literatura w otoczeniu cyfrowym zyskała charakter wielokodowy w stopniu nieporównanie większym niż kiedykolwiek wcześniej. Zmienił się sposób pojmowania tekstu, który traktujemy jako kategorię bardziej heterogeniczną, otwartą w większym stopniu na zewnętrzne odniesienia (hiperłącza) oraz gotową na kolejne przekształcenia $(\text { edycje })^{8}$. Relacja między nadawcą a odbiorcą okazała się przechodnia, a możliwość publikacji dostępna nieomal dla każdego zainteresowanego.

Można zatem powiedzieć, że współcześnie literatura podlega, po pierwsze, deterytorializa cji, co oznacza, że zostaje wywłaszczona z wydzielonej przestrzeni dyskursywnej, tracąc zaś odrębność, jednocześnie dzieli swoje właściwości z innego rodzaju tekstami. Po drugie, udziałem literatury stają się deprofesjonalizacja i egalitaryzacja. Twórca nie musi już dążyć do uzyskania prestiżowego statusu pisarza, potwierdzonego uznaniem w obrębie pola literackiego. Może odnieść sukces po prostu jako autor tekstów o rozmaitym charakterze, powieści albo wierszy, a zarazem relacji z podróży, poradnika z zakresu psychoterapii, przewodnika po muzyce hip-hopowej, diariusza albo internetowego bloga, zbioru felietonów. Przy czym publikacje o charakterze paraliterackim nie mają tu charakteru suplementarnego, nie dopełniają ani nie komentują „właściwej” twórczości, lecz z założenia stanowią pełnoprawne pozycje w dorobku. Choć zatem książka literacka odgrywa mniejszą rolę we współczesnej kulturze aniżeli było to w XIX lub XX wieku, to jednocześnie możemy szukać elementów „literackości” w książkach innego

7 Zob. H. Jenkins, Kultura konwergencji. Zderzenie starych i nowych mediów, przeł. M. Bernatowicz, M. Filiciak, Warszawa 2007.

8 Zob. B. Bodzioch-Bryła, Sploty: przeptywy, architektury, hybrydy. Polska e-poezja $w$ dobie procesualności i konwergencji, Kraków 2019. 
rodzaju, tekstach zamieszczanych w sieci (np. copypasty) lub nawet operujących innymi kodami niż werbalny (np. sztuki audiowizualne, seriale telewizyjne, gry komputerowe).

Rzecz jasna, wszystko to razem nie przeszkadza temu, że każdego roku nowe tomy konwencjonalnej, drukowanej prozy i poezji ukazują się w obfitości, której nie mogą podołać nie tylko najbardziej zdeklarowani czytelnicy, ale i bibliografowie. Twierdzę jednak, że również tradycyjny obieg znajduje się pod przemożnym wpływem współczesnej cyberkultury9. Skutkiem dokonującej się w jej obrębie re m e di a cji zmienia się nie tylko nośnik, ale również sposób organizacji tekstu oraz nawyki percepcyjne, co z kolei przekłada się na to, jak traktujemy tradycyjne książki. Kultura literacka nie zanika ani nie ustępuje miejsca czemuś innemu, lecz - włączona w obręb cyberkultury - funkcjonuje na nowych zasadach, przeobrażając się powoli w nową formułę, którą roboczo określiłbym mianem p o stlit te r a c k i j. A wszystko to oczywiście wpływa na kondycję krytyki.

\section{3}

W popularnym wykładzie Przewodnik po kulturze nowoczesnej dla inteligentnych Roger Scruton przypominał o „religijnych korzeniach” kultury. Jeśli w społeczeństwach przednowoczesnych religia sankcjonowała wspólnotę kultywującą obyczaje przodków, to na progu nowoczesności właśnie kultura (pojęcie ukute przez Johanna Gottfrieda Herdera) przejęła elementarną funkcję „powtarzania i odnawiania doświadczenia [...] przynależności” ${ }^{10}$. Proces ten dokonał się za cenę emancypacji kultury wobec religii oraz jej postępującej desakralizacji. Dlatego też samo pojęcie kultury okazuje się wewnętrznie sprzeczne. Możliwość powtarzania i odnawiania wspólnotowego doświadczenia jest nam dana wespół z nieuniknioną (bo niezbędną dla emancypacji) perspektywą krytyczną i autokrytyczną. Jak podnosił Scruton, krytyczna samoświadomość stanowi ,zagrożenie dla tego ładu, który [kultura - dop. K.U.] pragnie przecież uchronić" ${ }^{11}$. Oto paradoks: wszelka kultura może uchodzić za powszechną dopóty, dopóki sama nie rozpozna i nie zdefiniuje siebie jako kultury. Kryzys następuje wówczas, gdy odkrywamy, że kultura nie jest

9 Jak podkreśla Piotr Zawojski, nowy model kultury zakłada „synergię tego, co online, z tym, co offline" (P. Zawojski, Cyberkultura. Syntopia sztuki, nauki i technologii, Warszawa 2010, s. 100).

10 R. Scruton, Przewodnik po kulturze nowoczesnej dla inteligentnych, przeł. J. Prokopiuk, J. Przybył, Warszawa 2006, s. 14.

11 Ibidem, s. 21. 
depozytem, jaki został nam powierzony „z zewnątrz” i nie posiada żadnych metafizycznych gwarancji, ale jest tworem z „tego świata”, który regulują relacje władzy/wiedzy.

W konsekwencji prawomocną kulturą nowoczesną może być jedynie taka, która nieustannie pyta o własną prawomocność i powątpiewa w sformułowane przez siebie odpowiedzi. Naszą kulturę zatem określają, z jednej strony, permanentna produkcja samowiedzy, z drugiej zaś - tęsknota za "utraconą" powszechnością, jednością i jednorodnością. Podług tych dwóch motywów można by zapewne przeprowadzić elementarną typologię postaw oraz tendencji (artystycznych czy intelektualnych) w obrębie najszerzej pojętej nowoczesności. Trzeba jednak przy tym pamiętać, że motywy te nie są wyłącznie przeciwstawne, lecz powiązane ze sobą na mocy dialektyki, która w zasadniczym stopniu decydowała o zróżnicowaniu nowoczesności, będąc mechanizmem generującym rozmaitość postaw, projektów, zjawisk, prądów, nurtów, programów. Niejednokrotnie bywało przecież tak, że aktywność krytyczna wypływała nie z próby zakwestionowania, ale raczej z dążenia do rewindykacji jedności oraz reintegracji wspólnoty (czego współczesnym przykładem będzie chociażby neokonserwatyzm samego Scrutona).

Odkrywając swoją społeczno-polityczną genealogię oraz historyczny charakter, kultura musiała dostrzec i zmierzyć się ze zróżnicowaniem własnych form (np. spór starożytników z nowożytnikami, literatura Północy vs literatura Południa). Siłą rzeczy romantyczne pojęcie kultury narodowej $-\mathrm{z}$ językiem jako jej kluczowym medium - pozycjonowało ją w ramach dialektyki tożsamości i różnicy wobec innych narodowych kultur. Wszelako równie istotnym wyzwaniem okazało się zróżnicowanie wewnętrzne. W warunkach nowoczesności hierarchiczny układ poziomów, odpowiadający stratyfikacji społecznej, musiał być podtrzymywany przez upowszechnianie kultury dominującej. Ponieważ kultura elity pretendowała do miana ogólnonarodowej, jej twórcy stanęli przed zadaniem skomunikowania się z możliwie szerokim kręgiem odbiorców. Idea komunikacji nowoczesnej zakładała ekskluzywny charakter roli nadawcy (twórcy należeli bądź aspirowali do elity), a jednocześnie - inkluzywny charakter odbioru (jak pamiętamy z lat szkolnej edukacji, romantyczne księgi miały „zbłądzi[ć] pod strzechy”).

W takiej złożonej sytuacji koniecznością stało się pojawienie krytyki jako instancji pośredniczącej między różnymi formacjami kulturowymi, odmianami czy formami tej samej „kultury narodowej”, wreszcie między artystyczno-intelektualną elitą a publicznością spoza tego wąskiego kręgu. Przed laty Marian Płachecki w ten sposób opisywał to „odkrycie” z przełomu XVIII i XIX stulecia, które legło u podwalin instytucji:

Elita literacka, jeśli chce pozostać elitą, musi się zwrócić ku publiczności zewnętrznej, formułując własne wartości i interesy w terminach dostępnych 
„powszechności”. Z bezimienną i rozproszoną publicznością zewnętrzną porozumieć się można jedynie poprzez druk, ga ze tę i rynek ${ }^{12}$.

Warto zwrócić uwagę, że „druk, gazeta i rynek” jako najważniejsze instrumenty upowszechniania kultury „wysokiej” (gwarantujące zarazem utrzymanie pozycji elity, niechby za cenę - ograniczonej - „demokratyzacji” całego systemu komunikacji społecznej) decydowały zarazem o wyróżnionej pozycji literatury i krytyki literackiej, związanych z tym samym medium. Trzeba jednak podkreślić, że w istocie sprawy przedstawiały się niejednoznacznie, co w dwójnasób dotyczyło krytyki, która nie mogła sobie pozwolić na artystowską pogardę dla niekompetentnych odbiorców. Występując w imieniu elity, recenzenci od początku zwracali się do czytelników spoza własnego kręgu, a konfrontacja z gustami „,powszechności” nie zawsze przebiegała gładko, o czym przekonali się już członkowie Towarzystwa X-ów! ${ }^{13}$. Wprawdzie prestiż krytyki był usankcjonowany systemowo (zabierając głos, recenzent występował jako autorytet), niemniej prestiż ten był łatwy do zakwestionowania z tytułu nieokreśloności przedmiotu, niejednorodności i nieporównywalności kryteriów, mnogości konkurujących ze sobą formuł estetycznych. Krytyka okazała się również szczególnie zróżnicowana i niezgodna sama z sobą, targana wewnętrznymi konfliktami, wynikającymi choćby z nakładania się na siebie sprzecznych ról komunikacyjnych (np. popularyzacja, uzgadnianie common sense oraz - z drugiej strony - dążenie do różnicowania opinii i sądów), co przecież nie dotyczy samego tylko okresu dwudziestolecia międzywojennego...14

Dopiero pamiętając o tym wszystkim, możemy postawić pytanie o sytuację współczesną. Oto, gdzie - zdaniem Bernadetty Darskiej - tkwi największy problem:

Krytyka literacka musi zrezygnować z samozadowolenia i poczucia, że opinia osób zawodowo zajmujących się literaturą cokolwiek znaczy. To smutne, bo możemy dziś mówić nie tylko o upadku autorytetów, lecz także o coraz większym, by odwołać się do określenia Andrew Keena, kulcie amatora. Nie byłoby nic złego w tym, że tzw. zwykły czytelnik dzieli się publicznie swoimi opiniami, gdyby nie fakt, iż coraz częściej mają one większą wartość niż ocena krytyka ${ }^{15}$.

12 M. Płachecki, Przemiany roli społecznej krytyka 1764-1830. Rekonesans [w:] Badania nad krytyka literacka, S. II, red. M. Głowiński, K. Dybciak, WrocławWarszawa-Kraków-Gdańsk-Lódź 1984, s. 33 (podkr. oryg.).

13 Zob. I. Kitowiczowa, O zadaniach krytyki literackiej lat 1800-1820 [w:] Badania nad krytyka literacka, red. J. Sławiński, Wrocław-Warszawa-Kraków-Gdańsk 1975.

14 Por. D. Skórczewski, Spory o krytykę literacka w dwudziestoleciu międzywojennym, Kraków 2002.

15 B. Darska et al., Świadomość krytyki. Ankieta „Wielogłosu”, „Wielogłos” 2011, nr 1 (9), s. 9. 


\section{I dalej:}

Jest więc źle, bo - po pierwsze - krytyka mało kto chce słuchać, bo - po drugie krytyka ma coraz mniej miejsc, w których może mówić głośno, a więc słyszalnie, bo - po trzecie wreszcie - głos krytyka zostaje zrównany z głosem amatora ${ }^{16}$.

Na proces wypierania ekspertów przez ,amatorów” zwracają uwagę wszyscy uczestnicy ankiety, z której pochodzi przytoczona opinia. Pamiętajmy jednak, że konflikt zoilów ze „zwykłymi czytelnikami” wpisany jest w samą strukturę wypowiedzi krytycznej. Osobliwość obecnej sytuacji nie wynika zatem z prostej odmienności gustów czy postaw, lecz bierze się stąd, że tym razem konflikt przebiega pod dyktando drugiej strony! Jako „krytyk-amator” czytelnik nie tylko reprezentuje vocem populi, lecz przejmuje także ,rząd dusz", przechwytując publiczność, do której tradycyjnie zwracała się krytyka, i tym samym skutecznie wypierając „zawodowców” do środowiskowego rezerwatu, gdzie nad naszą recenzją może się pochylić najwyżej koleżanka lub kolega po fachu. Nic tedy dziwnego, że znacząco zmniejszyła się liczba tradycyjnych czasopism literackich, a działy kulturalne w prasie o szerszym adresie ustąpiły miejsca kolumnom lajfstajlowym.

Zmiana, o której mowa, nie byłaby możliwa bez nowych mediów i powszechnego dostępu do sieci internetowej. Dzięki Web 2.0 każdy czytelnik może publicznie przedstawić swoją opinię na temat przeczytanej książki, a jeśli ma dość motywacji, by robić to regularnie (na przykład w formie bloga), staje się „krytykiem-amatorem”, wokół którego skupia się mniejsza czy większa grupa odbiorców, zazwyczaj podzielających jego czytelnicze preferencje. Powód, dla którego „,amatorzy” zdobywają przewagę nad „zawodowcami”, jest prosty: czytelnik zakłada, że opiniodawca występujący wyłącznie jako miłośnik książek lub literatury, posiada podobne jak on sam potrzeby i skalę lekturowej wrażliwości, a jako taki wzbudza większe zaufanie. Nie bez znaczenia jest również łatwa dostępność internetowych blogów i portali czytelniczych, przy czym ich pozycjonowanie w wyszukiwarkach, zależne przede wszystkim od liczby odsłon, sprzyja utrwalaniu najbardziej rozpowszechnionych wyobrażeń na temat literatury. Nie znaczy to oczywiście, że nowe media z zasady wspomagają proces petryfikacji opinii. Sukces przynieść może także taktyka obliczona na zakłócanie konsensu pod warunkiem, że w ten sposób wytworzymy i skonsolidujemy wokół siebie osobną wspólnotę komunikacyjną (własną „,bańkę”). Jakkolwiek cnotą krytyki „amatorskiej” ma być jej „niezależność” (od koterii literackich), to w praktyce - przynajmniej w swoich początkach okazuje się podporządkowana interesom wydawnictw, z którymi współpracują poszczególni opiniodawcy, zobowiązani do rekomendowania z góry określonego odsetka otrzymanych publikacji. Można jednak zakładać, że z czasem

\footnotetext{
16 Ibidem.
} 
nowy obieg krytyczny wyłoni liderów, którzy będą potrafili dyktować warunki redakcjom i firmom wydawniczym, zabezpieczając przy tym swoją niezależność. Inna rzecz, że taki scenariusz wymagałby stopniowej... profesjonalizacji amatorskiego zrazu obiegu. Właśnie! Jak się okazuje, istotna dystynkcja nie musi wcale przebiegać zgodnie z kryterium profesjonalizmu. Wszak wraz z pozyskaniem odpowiedniej liczby odbiorców „krytyka amatorska” może się okazać wcale dochodowym przedsięwzięciem (na przykład dzięki reklamom zamieszczonym na blogu), podczas gdy „krytyka zawodowa” coraz częściej bywa uprawiana jako działalność non profit. Dalej, „krytyka amatorska” jest „natywnie” związana z nowymi mediami oraz Internetem, ale przecież „zawodowcom" również zdarza się funkcjonować za pośrednictwem mediów cyfrowych ${ }^{17}$. Jak się wydaje, w rozumieniu Darskiej „zawodowstwo” kryptonimuje związek z kulturą literacką rozumianą korporacyjnie i merytokratycznie, a więc jako struktura odwzorowująca reguły komunikacji typograficznej. W tym sensie ,zawodowcem” byłby doktorant literaturoznawstwa omawiający tomik wierszy w czasopiśmie, które nie płaci za publikację, ale za to selekcjonuje teksty pod kątem ich zgodności z wymaganiami tak czy inaczej rozumianego dyskursu krytycznego. Tymczasem „amator” funkcjonowałby w takiej przestrzeni medialnej, która obywałaby się bez figury symbolicznego strażnika ${ }^{18}$, dysponującego władzą dopuszczania tekstów do obiegu, a jednocześnie potwierdzającego ich merytoryczną wartość. Krytyka nowego wzoru funkcjonowałaby $\mathrm{w}$ ramach otwartej przestrzeni komunikacyjnej. Przynajmniej „na wejściu”, bo już „na wyjściu” sprawy by się komplikowały. Kiedy bowiem każdy zainteresowany może pisać i publikować, wówczas zdobycie względów odbiorcy staje się sprawą jeszcze ważniejszą niż w ramach kultury masowej, same zaś teksty różnicuje w pierwszej kolejności liczba odsłon i rekomendacji.

17 Warto nadmienić, że jeden z bardziej popularnych polskich blogów książkowych prowadzi od roku 2015 cytowana wyżej Bernadetta Darska, zob. http://bernadettadarska. blogspot.com [dostęp: 25.07.2019].

18 Figura „strażnika bramy kulturowej” (cultural gatekeeper) pojawia się w przywołanej przez Darską głośnej książce Andrew Keena Kult amatora. Jak Internet niszczy kulturę, przeł. M. Bernatowicz, K. Topolska-Ghariani, wprowadzenie K. Krzysztofek, Warszawa 2007, s. 32 i n. Ten inteligentny pamflet na kulturę Web 2.0 należy do publikacji inspirujących i prowokujących (do dyskusji), warto jednak podkreślić, że argumentacja Keena i podobnych mu autorów w zasadniczych punktach przypomina... Platońską krytykę pisma! Wygląda na to, że krytyczne reakcje na pojawienie się „,nowego medium” operują dość ograniczoną liczbą zagrożeń, wskazując na niebezpieczeństwa związane z mechanizacją i nieautentycznością nowej formacji, tryumfem dyletantyzmu czy degradacją prawdy. W trybie parodii posłużył się tym schematem Sapkowski w jednej ze scen powieści Narrenturm, gdzie Samson Miodek - niczym faraon z paraboli Platona - odprawia z kwitkiem Teuta-Gutenberga, zob. A. Sapkowski, Narrenturm, Warszawa 2006, s. 259-262. 
Wszelako z perspektywy nowych mediów różnica między figurą ,amatora" a ,zawodowca” jawi się tak niewyraźnie ${ }^{19}$, że w gruncie rzeczy nie daje podstaw do przeprowadzenia rozgraniczeń między tradycyjną (związaną z medium druku) i nową formułą krytyki. Znowu zatem dystynkcji musimy szukać gdzie indziej. Przepatrzywszy argumenty pojawiające się w ramach debaty między stronami (tj. krytykami „,papierowymi” i blogerami), Krzysztof Hoffmann stwierdza: „Najpoważniejszy zarzut wobec blogerów dotyczy strony merytorycznej. [...] W konfrontacji z tradycyjną krytyką papierową, rywalizując pod względem jakości tekstów, blog musi przegrać"20. Oczywiście nie znaczy to, że krytyka tradycyjna jest z zasady „,bardziej wartościowa”. Wszak blogerzy książkowi (ponieważ blog jest najbardziej charakterystyczną formą krytyki w sieci, figurę blogera traktuję jako metonimię całego nowego modelu) często są absolwentami kierunków humanistycznych (choć, rzecz jasna, nie stanowi to żadnego warunku). Poza tym w obiegu internetowym funkcjonują czasopisma oraz portale literackie redagowane wcale starannie, bez względu na to, czy w roli autorów występują tu krytycy znani z obiegu drukowanego, czy nie, i czy podpisują się oni swoimi nazwiskami, czy też korzystają z wymyślnych, anglojęzycznych (najczęściej) pseudonimów. Nic nie stoi na przeszkodzie, aby tekst krytyczny zamieszczony w Internecie był równie wartościowy merytorycznie, jak ten opublikowany w branżowym czy wręcz akademickim periodyku. Okazuje się jednak, że tym razem nie chodzi już o wymóg systemowy, lecz właściwość o charakterze sekundarnym. Wynika stąd, że kryterium merytoryczne jest istotne dla kultury druku, w ramach zaś cyberkultury odgrywa mniejszą rolę. Można więc powątpiewać, czy krytykę funkcjonującą w sieci należy rozpatrywać z punktu widzenia jej wartości merytorycznej, a jeśli nawet tak, to czy przypadkiem nie dowodzimy w ten sposób wyłącznie naszego własnego odchylenia typograficznego, za sprawą którego teksty z sieci skłonni jesteśmy traktować tak, jakby były tekstami drukowanymi.

Nie ulega wątpliwości, że nowe media redefiniują nie tylko pojęcia literatury czy krytyki, ale także zmieniają zakres kompetencji wymaganych od autorów i czytelników. Autor musi nabyć przynajmniej podstawowe umiejęt-

19 Jak przenikliwie zauważył Andrzej Skrendo, „w kulturze Internetu zanikaniu podziału na autora i czytelnika towarzyszy zanikanie podziału na profesjonalistę i nieprofesjonalistę [...], kto bada czytelnictwo w Internecie, powinien być świadom, że Internet nie tyle stanowi uprzywilejowane forum ekspresji dla nieprofesjonalistów, ile ni e p ozwala odróżnić profesjonalisty od nieprofesjonalisty. Zaciera a lbo unieważnia tę różni cę" (A. Skrendo, Nieprofesjonalne świadectwa lektury [w:] Obraz literatury w komunikacji społecznej po roku '89, red. A. Werner, T. Żukowski, Warszawa 2013, s. 199-200 - podkr. K.U.).

20 K. Hoffmann, Hejtuję blogi? Blogi o literaturze a krytyka literacka [w:] Literatura $w$ mediach, media $w$ literaturze, t. 3, red. K. Taborska, W. Kuska, Gorzów Wielkopolski 2014, s. 59-60. 
ności z zakresu redagowania i edycji tekstu (związane między innymi z wykorzystywaniem odpowiednich programów komputerowych), czytelnik musi obsługiwać interfejsy, sprawnie nawigować w sieci, docierać i korzystać z baz danych. $Z$ drugiej strony, ich obu nie obowiązują w sposób ścisły niektóre z wymagań wypracowanych $\mathrm{w}$ ramach kultury druku. Tekst opublikowany w sieci nie musi być wersją finalną (lub możliwie najbliższą finalnej). Może być wariantem roboczym, szkicem, zbiorem pomysłów (w kulturze typograficznej dzieło fragmentaryczne czy też tak zwane dzieło w ruchu było najczęściej artystyczną stylizacją lub - jeśli istotnie zostało nieukończone - podlegało kodyfikacji w toku pracy nad edycją). Skutkiem takich działań okazało się obniżenie progu tolerancji dla rozmaitych niedoskonałości. Mało tego. Jedna $\mathrm{z}$ badaczek dyskursu nowych mediów pisze wręcz o zjawisku funkcjonalnego analfabetyzmu, ponieważ użytkownicy Web 2.0 (zwłaszcza ci młodsi) mają coraz większe kłopoty z syntetyzowaniem znalezionych informacji, a ich własne teksty odbiegają od kanonów piśmienności na rzecz zasad charakterystycznych dla organizacji wypowiedzi mówionej, nierozerwalnie związanej z kontekstem sytuacyjnym ${ }^{21}$. „Nowa piśmienność” faworyzuje układ nieciągły, modularny, zachęca do wzmożonej interferencji pisma z elementami ikonicznymi, ma charakter interaktywny, co służy przemienności ról nadawczo-odbiorczych i symulowaniu bezpośredniego kontaktu. Odstępujemy natomiast od zasad linearności i ciągłości wypowiedzi oraz kumulatywnego przyrastania sensów.

Jeśli jednak „nowa piśmienność” może być uznana za rodzaj analfabetyzmu lub piśmienności zdefektowanej, to wyłącznie z perspektywy norm wypracowanych przez kulturę typograficzną. Tak naprawdę, mamy tu świadectwo anachroniczności tych norm i - pośrednio - naszej bezradności, bo jako osoby, które zinterioryzowały klasyczne reguły piśmienności, nie potrafimy bez uprzedzeń spojrzeć na teksty przystosowane do wymagań cyberkultury. Miał tego świadomość Krzysztof Hoffmann, dlatego w zakończeniu swojego szkicu powstrzymał się i przestrzegał przed pochopnym negowaniem wartości książkowych blogów (jakkolwiek opowiedział się również za utrzymaniem bariery heterogeniczności między ,prawdziwą" krytyką a internetowym blogerstwem $)^{22}$. Podobnie jak to było w przypadku kategorii profesjonalizmu, również merytoryczna wartość tekstu krytycznego zostaje w ramach cyberkultury podważona $\mathrm{w}$ tym sensie, że tekst taki traci swoją przewagę nad innym, uboższym pod tym względem. Nie znaczy to, że merytoryczność stała się balastem, którego należy czym prędzej się pozbyć. Znaczy to wyłącznie, że cyberkultura nie skłania do różnicowania wypowiedzi krytycznych z uwagi na ten aspekt (a przynajmniej, że merytoryka nie stanowi tu istotnego kryte-

21 Zob. A. Skudrzyk, Czy zmierzch kultury pisma? O synestezji i analfabetyzmie funkcjonalnym, Katowice 2005.

22 Zob. K. Hoffmann, op.cit., s. 60-62. 
rium). Parafrazując św. Pawła (1 Kor 7, 29-31), powiedzielibyśmy zatem, że trzeba dziś, iżby i merytoryczni [krytycy - dop. K.U.] jak ni e merytoryczni byli, i poważni jak nie poważni, i błyskotliwi jak ni e błyskotliwi, i doniośli j a k n i e doniośli. Przemija bowiem formuła znanej nam kultury.

\section{4}

Poszukując właściwości, która decydowałaby o specyfice wypowiedzi krytycznej w obrębie formacji postliterackiej, a zarazem stanowiłaby jej najbardziej pożądaną jakość, rozważmy pewien przykład. Jak się za chwilę okaże, nie sięgnąłem do żadnego z książkowych blogów, lecz do uprawianej w Internecie „amatorskiej” krytyki filmowej. Rozwija się ona szybciej niż jej literacki (czy postliteracki) odpowiednik, trafia do szerszego grona odbiorców, chętniej korzysta z możliwości stwarzanych przez transmedialny charakter cyberkultury. $Z$ naszego zresztą punktu widzenia sam przedmiot krytycznych uwag jest mniej istotny, ważniejsza - konwencja, jaka została tu wypracowana. By mieć pewną skalę porównawczą, przejrzałem komentarze dotyczące produkcji cieszącej się szczególną popularnością i mogłem się przekonać, że ostatni sezon serialu telewizyjnego Gra o tron (HBO, 2011-2019) był w polskim Internecie omawiany na bieżąco zarówno na kanałach kultywujących w ramach nowego medium tradycję krytyki eksperckiej (np. youtubowe i fejsbukowe Jakbyniepaczeć Kai Szafrańskiej i Janusza Raczyńskiego), jak i tych operujących większą skalą ekspresji, swobodniejszym stylem, zabiegających o nawiązanie bardziej bezpośredniej relacji z odbiorcami i dbających o walory rozrywkowe. Tak czy owak, chodziło o filmy, które trwają pół godziny i więcej, nagrywane w domowych warunkach lub zaimprowizowanych studiach, z komentarzem omawiającym szczegóły nawet pojedynczych serialowych odcinków. Nie bez powodu Michał Lipiński - jeden z wyróżniających się autorów, gospodarz kanału Szybkie recenzje - wyznał (polszczyzną dość specyficzną, bo operującą składniową kalką z języka angielskiego), że jest ,emocjonalnie zainwestowany w tę historię [chodziło właśnie o serial HBO - dop. K.U.]”23. Nie przeszkodziło mu to jednak w złożeniu rozlicznych dowodów doskonałej znajomości rzeczy (przynajmniej na poziomie fanowskim), analitycznej uwagi i krytycznej przenikliwości. Dzieląc się przemyśleniami po obejrzeniu ostatniego odcinka, Lipiński całkiem przytomnie zwrócił uwagę, że winą za niedomagania końcowych sezonów nie można obarczyć wyłącznie serialowych

${ }^{23}$ Gra o tron - finat S08E06, na kanale Michała Lipińskiego „Szybkie recenzje”. Wypowiedź z 00:35-00:36 filmu (youtube.com/watch?v=RSE4CUsLNq8 [dostęp: 27.06.2019]). Przy kolejnych cytatach czas, w którym padają przywołane słowa, podaję bezpośrednio w tekście głównym. 
storytellerów, bo wraz z kolejnymi tomami sagi również autor literackiego pierwowzoru, sam George R.R. Martin ,zaczął pisać siedemset tysięcy wątków pobocznych zamiast skondensować historię" (11:15-11:18). W dodatku wiele z tych wątków okazało się kiepsko umotywowanych z punktu widzenia logiki fabularnej całego cyklu. Posłuchajmy recenzenta:

Nagle mamy [chodzi o Ucztę dla wron, czwartą część sagi - dop. K.U.] dziesięć rozdziałów typu „Brienne jeździ konno z Podrickiem, szukając gdzieś tam po Westeros Sansy” i to są wszystko rozdziały typu „Dzień dobry, zastałam Sansę? Nie?” No to jedzie dalej, wpada na kogoś, takie, powiedzmy, smęty [10:35-10:47].

Mniejsza o potocyzmy i wszystkie inne wykładniki stylu mówionego. Zastrzeżenia Lipińskiego wydają się uzasadnione przynajmniej dopóty, dopóki cykl utworów amerykańskiego pisarza będziemy gotowi rozważać pod kątem wymogów takich opowieści, w ramach których właśnie fabule przypadałaby rola kluczowej figury semantycznej. Równie dobrze można jednak przyjąć, że w miarę postępu cyklu narracja u Martina przeobraziła się z fabułocentrycznej w światocentryczną! Przy takim założeniu domniemany błąd w pisarskiej sztuce okazałby się przemyślanym zabiegiem, wszystkie zaś „,smęty”, kolejne i kolejne wątki poboczne, tak nużące dla wielu dotychczasowych fanów, nie służyłyby już prowadzeniu intrygi i rozwijaniu historii, lecz były podporządkowane dążeniu do narracyjnego uzupełniania mentalnej mapy fikcyjnego świata! Jeśli tak, to nie może nas dziwić, że Martin od długiego już czasu ma kłopoty z kontynuacją cyklu i domknięciem fabuły. Dążenie do rozstrzygnięcia perypetii staje bowiem w oczywistej sprzeczności z wymogami narracji światocentrycznej! Nie twierdzę zatem, że pretensje recenzenta na pewno są słuszne. Warto je jednak przemyśleć i podjąć z nimi dyskusję.

Sądzę natomiast, że krytyka wyrastająca z doświadczenia nowych mediów nie jest zorientowana wyłącznie na funkcję rozrywkową i że nie musi mieć aintelektualnego charakteru. Istnieje jednak ważna różnica między dobrze nam znaną, refleksyjną formułą krytyki a tą nową, kształtującą się właśnie na naszych oczach. By ją uchwycić, pozostańmy przy Grze o tron, pozostańmy również przy mediach elektronicznych, lecz tym razem przyjrzyjmy się nie filmom, lecz plikom tekstowym zamieszczanym na portalu fsgk.p ${ }^{24}$. Autorami wątków związanych z uniwersum GoT (zarówno cyklu powieści Martina, jak i serialu produkcji $\mathrm{HBO}$ ) są tu różne osoby, grupa posiada jednak wyraźnego lidera, podpisującego się inicjałami DaeL. Jeszcze w roku 2014, przy okazji artykułu inicjującego cykl „Szalone teorie”, w ramach którego prezentowane

24 Portal wyrósł z internetowego forum czasopisma „Świat Gier Komputerowych”, które ukazywało się w latach 1992-2003. 
są spekulacje dotyczące rozmaitych tajemnic i zagadek alternatywnego uniwersum, możliwych wariantów dalszego biegu wydarzeń, ukrytych motywacji poszczególnych postaci itp., lider grupy pisał:

Jednym z ulubionych środków literackich stosowanych przez George'a R.R. Martina jest tzw. foreshadowing - rodzaj niepozornej sugestii przyszłych wydarzeń, często wplecionej w dyskusje niezwiązane $\mathrm{z}$ samym tematem zapowiedzi. Część tego typu zabiegów wiąże się w stworzonym przez GRRM-a świecie z magią (mamy więc np. nieświadome przepowiednie), część jednak jest po prostu literacką zabawą ${ }^{25}$.

Co prawda, na wstępie artykułu komentator wyraźnie się asekurował: „Część prezentowanych przeze mnie teorii okaże się pewnie nieprawdziwa. Część będzie silnie nacechowana - typowymi dla teorii spiskowych - błędami poznawczymi. Niejeden raz damy się podpuścić autorowi i niejeden raz polegniemy w starciu z efektem potwierdzania lub widzeniem tunelowym"26. Rozumiemy zatem, że przy okazji pierwszej i wszystkich kolejnych „,szalonych teorii" podążamy po wąskiej ścieżce, odgraniczającej uważną i wnikliwą analizę od nadinterpretacji o znamionach poznawczej paranoi. Co więcej, musimy się liczyć z tym, że najpewniej niejeden raz zdarzy się nam tę granicę przekroczyć. A jednak pierwszy z cytowanych fragmentów sugeruje wyraźnie, że w ten sposób nie tylko dajemy upust swojej interpretacyjnej woli mocy. Rzecz w tym, że równocześnie podejmujemy strategię odbiorczą zaproponowaną w samym tekście i zaprojektowaną przez jego twórcę. Cała trudność wynika stąd, że rozrzucone w utworze wskazówki i antycypacje najczęściej bywają zawoalowane. Trudno zatem o pewność, że za każdym razem trafiliśmy na taką właśnie ukrytą podpowiedź. Nie można bowiem wykluczyć, że przynajmniej od czasu do czasu zdarzy się nam pobłądzić, skutkiem czego pochopnie doszukujemy się utajonych treści akurat tam, gdzie po prostu ich nie ma. Takiej świadomości towarzyszyć wszakże musi inne spostrzeżenie, że nasza sytuacja nie odbiega zasadniczo od tej, w jakiej znajduje się każdy inny egzegeta, który oczywiście stara się jak najlepiej uzasadnić i uprawdopodobnić własną wykładnię, lecz przecie nie może jej zweryfikować w sposób pewny, ponieważ nie posiada dostępu do znaczenia tekstu inaczej jak tylko poprzez jego - takie czy inne - zapośredniczenie!

Trzeba jednak pójść dalej i wykroczyć poza ten hermeneutyczny banał. Zauważmy na początek, że w konsekwencji nie tylko jesteśmy skazani na interpretacyjną niepewność. Samo interpretowanie zakrawa na praktykę, której nigdy nie sposób (ostatecznie) uprawomocnić, metodologicznie i teo-

25 DaeL, Szalone teorie: Kim sq rodzice Jona Snow?, portal fsgk.pl, fsgk.pl/wordpress/2014/06/zwariowane-teorie-kim-sa-rodzice-jona-snow [dostęp: 27.06.2019].

26 Ibidem. 
retycznie uzasadnić (raz na zawsze - przynajmniej w obrębie określonej épistéme), potwierdzić w taki sposób, który sam wymykałby się możliwości zakwestionowania. Można zatem powiedzieć, że interpretacja jako taka wykracza poza ramy logiki dwuwartościowej i zasady wyłączonego środka - tak wyglądałaby jedna z możliwych wykładni radykalnej hermeneutyki. Przynajmniej na gruncie „szalonych teorii”. Trzeba jednak natychmiast dodać, że z takiego punktu widzenia nie ma i nie może być innych „teorii” niż te doprawione elementem poznawczego szaleństwa, tymi zaś, które nie przyjmują tego do wiadomości, po prostu nie warto zawracać sobie głowy, bo też nigdy nie doprowadzą nas do niczego ciekawego. Właśnie! Niemożność ostatecznego rozróżnienia pomiędzy interpretacją wnikliwą a nadinterpretacją stawia pod znakiem zapytania granicę pomiędzy heurystyką a praktyką ludyczną. Wszelako w ramach zarysowującej się tu optyki w stronę niebezpiecznej etycznie (społecznie, politycznie) nadinterpretacji nie prowadziłyby nas dociekania eksponujące swój aspekt ludyczny (choć z tradycyjnego punktu widzenia właśnie pod ich adresem formułowalibyśmy zarzut interpretacyjnego nihilizmu), lecz zupełnie na odwrót - kontrowersyjna byłaby praktyka, która wzdraga się przed zabawą oraz ironią i która własne rozstrzygnięcia uznaje za ostateczne.

Oprócz trybu krytycznego komentarza, zawierającego w sobie tyleż interpretację, co jej dekonstrukcję, na uwagę zasługuje coś jeszcze. Wywody DaeLa przybierają taką postać, że ich autor w pełni zasadnie mógłby powiedzieć - razem z Michałem Lipińskim - iż jest „emocjonalnie zainwestowany w tę [komentowaną przez siebie - dop. K.U.] historię". Chodzi o coś więcej niż samą uważną i zapewne wielokrotną lekturę powieści Martina (choć już to budzi uznanie wśród autorów zamieszczonych pod artykułem postów). „Szalone teorie” Daela i jego kolegów należy traktować nie tylko jako próby wyjaśnienia tajemnic uniwersum GoT, funkcjonują one bowiem jako jego uzupełnienie czy - to chyba lepsze określenie - rozs zer zen i e. Są związane z próbą rekonstrukcji tła konfliktów w fikcyjnym świecie, czemu towarzyszy wskazywanie odniesień poszczególnych motywów i wątków do szeroko pojętej kulturowej tradycji, przeprowadzanie historycznych paralel itp. Wszelako w tym przypadku komentarz nie sytuuje się na metapoziomie i nie dotyczy tekstu jako całości, wyraźnie wydzielonej z literackiej przestrzeni. Stawką jest raczej przetworzenie i prze-pisanie komentowanego dzieła w taki sposób, by przez uruchomienie domyślnych „linków” przemieścić je w szerszą, hipertekstową płaszczyznę. Przy takiej zaś okazji aktualizacji i rekonfiguracji podlega cała grupa intertekstów, które znalazły się w polu wzajemnego oddziaływania.

Oczywiście filolodzy, literaturoznawcy, krytycy, uczeni w piśmie wszystkich czasów zawsze z upodobaniem wskazywali wszelkie aluzje i inne międzytekstowe zależności. Służyło to jednak egzegezie komentowanego dzieła, a ponadto podnosiło jego autorytet przez wykazanie związków z czcigodną 
tradycją ${ }^{27}$. Wszelako tym razem stawką nie jest systemowe potwierdzenie, lecz nieustająca rekonfiguracja pola odniesień, sama zaś tradycja, kanon, „poetycka centrala”, mainstream przestają funkcjonować jako źródło legitymizacji dzieła. Przeciwnie, to raczej one potrzebują legitymizowania w toku nieustannych aktualizacji.

Warto zauważyć, że opisywana tu formuła krytyczna ma wiele wspólnego z tą specyficzną praktyką (post)literacką, jaką jest fanfiction. Oczywiście, zjawisko wspólnot fanowskich wyrosło z dwudziestowiecznej kultury popularnej, a sama fanfiction narodziła się w magazynach wydawanych własnym sumptem przez członków fandomu. Wszelako cyberkultura stworzyła szczególnie przyjazne warunki dla rozwoju tej formy aktywności, a w konsekwencji poczęła ona uchodzić za jedną z modelowych praktyk współczesnej kultury $^{28}$. W artykule z roku 2013 Przemysław Czapliński wskazał na twórczość fanowską jako działalność, która przeobraża dotychczasowe rozumienie literatury i komunikacji literackiej. Odwołując się do jednej z książek Henry'ego Jenkinsa (Textual Poachers, 1992) ${ }^{29}$ oraz opracowania Johna Storeya ${ }^{30}$, Czapliński pisał:

Czytając, fan szuka szczelin, luk, niedopowiedzeń, czyha na okazje do rozpoczęcia własnej opowieści. Jest to również kultura czytania wielokrotnego, łączącego rygoryzm z liberalizmem: fani dobrowolnie akceptują wyjściowe ograniczenia (przejmując od oryginału bohaterów czy jakąś linię fabularną), a zarazem przyznają sobie prawo do ustawicznego ingerowania w oryginał. I wreszcie jest to kultura wspólnotowa $^{31}$.

27 W ramach dialektyki kultury kwestionowanie tradycji przez romantycznego poetę bądź awangardowego artystę potwierdzało jedynie zwrotną zależność nowoczesnej estetyki od przedmiotu jej negacji.

${ }_{28}$ Z obszernej - także w języku polskim - literatury przedmiotu na szczególną uwagę zasługuje monografia Aldony Kobus Fandom. Fanowskie modele odbioru, Torun 2018. Zob. także poprzedzające tę publikację artykuły autorki: eadem, Fanfiction a funkcjonowanie literatury popularnej. Zarys perspektywy historycznej, „Kultura Popularna” 2013, nr 3 (37), s. 146-158; eadem, Literatura archontyczna. Fanfiction a struktura tekstu popularnego, „Tekstualia” 2014, nr 2 (37), s. 111-123.

29 W roku 2013 ukazała się nowa, zaktualizowana (,updatowana”), rocznicowa edycja tej pracy, zob. H. Jenkins, Textual Poachers: Television Fans and Participatory Culture. Updated Twentieth Anniversary Edition, New York-London 2013. Rozszerzona tytulatura tego wydania stanowi oczywiście przekorne nawiązanie do remasterowanych reedycji płyt CD lub DVD/Blu-ray.

30 J. Storey, Studia kulturowe i badania kultury popularnej. Teorie i metody, przeł. i red. J. Barański, Kraków 2003.

31 P. Czapliński, Literatura jest gdzie indziej [w:] Obraz literatury w komunikacji..., s. $121-122$. 
Czapliński podnosił również, iż „fani zaczynają siebie sytuować w opozycji do czytelników literatury wysokiej, dla których czytanie, oparte na zasadzie nienaruszalności tekstu, spełnia się w czynnościach zrytualizowanych i odseparowanych od życia" ${ }^{32}$. Spostrzeżenie tym bardziej interesujące, że jego autor to jeden $z$ najbardziej cenionych polskich krytyków. Tymczasem dokonujące się współcześnie zmiany, które mocno zachwiały instytucją krytyki, zostały tu potraktowane nie tylko bez cienia resentymentu, lecz także opisane z wyraźną sympatią.

Do uwag Czaplińskiego (i Jenkinsa) chciałbym dorzucić tezę: aktyw ność fanowska stanowi model dla działalności krytycznej w warunkach określanych przez cyberkulturę. W tym ujęciu krytyk nie funkcjonowałby już jako certyfikowany znawca, który zwracając się do czytelnika, potwierdza swoją osobną, wydzieloną, ekskluzywną pozycję. Tym razem występowałby po prostu jako miłośnik (lub hejter), który, owszem, może i powinien okazać nieprzeciętne kompetencje merytoryczne, interpretacyjną inwencję, retoryczną sprawność... Wszelako wszystko to łącznie nie miałoby żadnego znaczenia, jeśliby w jego wystąpieniu zabrakło miejsca dla świadectw afektywnego zaangażowania, za którego sprawą komentowany tekst literacki z przedmiotu refleksji przeobrażałby się w obiekt pożądania! Bo to właśnie afekt stanowi podstawę wspólnoty fanowskiej jako - przytaczam tu definicję Aldony Kobus - „kolektywnie konstruowanego fantazmatu na temat popkulturowych treści" ${ }^{\prime 33}$.

W odróżnieniu od twórców fanfiction krytyk oczywiście nie opowiada, nie rozwija wątków pobocznych, nie dopisuje przedakcji ani kontynuacji... Jednak wszystkie zebrane przez siebie dane wykorzystuje dla potrzeb interpretacyjnego fantazmatu, będącego zamiennikiem i przybliżeniem, a jednocześnie czynnikiem, który wymusza przemieszczenie (remediację!) tekstu o charakterze archontycznym (którym oczywiście nie musi być wyłącznie dzieło powstałe w kręgu kultury popularnej). Krytyk byłby tu więc kimś innym niż egzegetą, odkrywającym ukryte (głębokie) sensy komentowanego przez siebie utworu. Byłby wytwórcą szczególnego rodzaju „tekstów transformacyjnych czy też przeobrażonych" ${ }^{34}$, które mogą i powinny służyć pobudzaniu komunikacji, rekonfigurowaniu wyobrażeń związanych z poszczególnym dziełem, określoną konwencją lub nawet literaturą jako taką.

32 Ibidem, s. 122.

33 A. Kobus, Fandom..., s. 20.

34 M. Lisowska-Magdziarz, Fandom dla początkujących, cz. II: Tożsamość i twórczość, Kraków 2018, s. 8. Dokument elektroniczny na stronie www IDMiKS UJ - https://media.uj.edu.pl/documents/1384650/134373778/Lisowska-M-Fandom-dla-poczatkujacychCZESC-2.pdf/0295ffa2-8db0-4c6a-aee0-e300ea39cbc8 [dostęp: 26.07.2019]. 


\section{Bibliografia}

10 opinii o czytelnictwie w Polsce, którymi zabłyśniesz $w$ towarzystwie, 26.03.2019, blog czytelniczy.pl, http://czytelniczy.pl/czytelnictwo-w-polsce-2019/ [dostęp: 21.06.2019].

Bodzioch-Bryła B., Sploty: przeplywy, architektury, hybrydy. Polska e-poezja w dobie procesualności i konwergencji, Kraków 2019.

Czapliński P., Literatura jest gdzie indziej [w:] Obraz literatury w komunikacji społecznej po roku '89, red. A. Werner, T. Żukowski, Warszawa 2013.

DaeL, Szalone teorie: Kim sa rodzice Jona Snow?, portal fsgk.pl, fsgk.pl/wordpress/2014/06/zwariowane-teorie-kim-sa-rodzice-jona-snow [dostęp: 27.06.2019].

Darska B. et al., Świadomość krytyki. Ankieta ,, Wielogłosu”, „,Wielogłos” 2011, nr 1 (9).

Gra o tron - finat S08E06, na kanale Michała Lipińskiego „Szybkie recenzje”, youtube.com/watch?v=RSE4CUsLNq8 [dostęp: 27.06.2019].

Habermas J., Strukturalne przeobrażenia sfery publicznej, przeł. W. Lipnik, M. Łukasiewicz, red. M. Czyżewski, Warszawa 2007.

Hoffmann K., Hejtuje blogi? Blogi o literaturze a krytyka literacka [w:] Literatura $w$ mediach, media $w$ literaturze, t. 3, red. K. Taborska, W. Kuska, Gorzów Wielkopolski 2014.

Jenkins H., Kultura konwergencji. Zderzenie starych i nowych mediów, przeł. M. Bernatowicz, M. Filiciak, Warszawa 2007.

Jenkins H., Textual Poachers: Television Fans and Participatory Culture. Updated Twenty Anniversary Edition, New York-London 2013.

Keen A., Kult amatora. Jak Internet niszczy kulture, przeł. M. Bernatowicz, K. Topolska-Ghariani, wprow. K. Krzysztofek, Warszawa 2007.

Kitowiczowa I., O zadaniach krytyki literackiej lat 1800-1820 [w:] Badania nad krytyka literacka, red. J. Sławiński, Wrocław-Warszawa-Kraków-Gdańsk 1975.

Kobus A., Fandom. Fanowskie modele odbioru, Torun 2018.

Kobus A., Fanfiction a funkcjonowanie literatury popularnej. Zarys perspektywy historycznej, „Kultura Popularna” 2013, nr 3 (37).

Kobus A., Literatura archontyczna. Fanfiction a struktura tekstu popularnego, „Tekstualia" 2014, nr 2 (37).

Koryś I., Chymkowski R., Stan czytelnictwa w Polsce w 2018 roku. Wstępne wyniki, https://www.bn.org.pl/download/document/1553593649.pdf [dostęp: 21.06.2019].

Lisowska-Magdziarz M., Fandom dla początkujących, cz. II: Tożsamość i twórczość, Kraków 2018, s. 8, https://media.uj.edu.pl/documents/1384650/134373778/Lisowska-M-Fandom-dla-poczatkujacych-CZESC-2.pdf/0295ffa2-8db0-4c6a-aee0-e300ea39cbc8 [dostęp: 26.07.2019].

Maryl M., Technologie literatury. Wpływ nośnika na formę i funkcję przekazu literackiego, „Pamiętnik Literacki” 2010, nr 2.

Miller J.H., O literaturze, przeł. K. Hoffmann, Poznań 2014.

Płachecki M., Przemiany roli społecznej krytyka 1764-1830. Rekonesans [w:] Badania nad krytyka literacka, S. II, red. M. Głowiński, K. Dybciak, WrocławWarszawa-Kraków-Gdańsk-Łódź 1984. 
Sapkowski A., Narrenturm, Warszawa 2006.

Scruton R., Przewodnik po kulturze nowoczesnej dla inteligentnych, przeł. J. Prokopiuk, Jan Przybył, Warszawa 2006.

Skórczewski D., Spory o krytykę literacka $w$ dwudziestoleciu międzywojennym, Kraków 2002.

Skrendo A., Nieprofesjonalne świadectwa lektury [w:] Obraz literatury w komunikacji społecznej po roku '89, red. A. Werner, T. Żukowski, Warszawa 2013.

Skudrzyk A., Czy zmierzch kultury pisma? O synestezji $i$ analfabetyzmie funkcjonalnym, Katowice 2005.

Storey J., Studia kulturowe i badania kultury popularnej. Teorie i metody, przeł. i red. J. Barański, Kraków 2003.

Szestowicki J., Biadoląc, że „28\% Polaków i Polek nie ma w domu książki” prosicie się o śmiech lub maść na ból dupy, https://noizz.pl/opinie/dzien-ksiazki-2019-polacy-nie-czytaja-jak-promowac-ksiazki-zeby-to-mialo-sens/fjgfjzn [dostęp: 21.06.2019].

Świadomość krytyki. Ankieta „,Wielogłosu”, „Wielogłos” 2011, nr 1 (9).

Woodmansee M., The Author, Art, and The Market. Rereading the History of Aesthetics, New York 1994.

Wysocki G., Martwisz się, że Polacy nie czytaja ksiażek? To znaczy, że jesteś snobem. Absurdalna awantura o klasizm czytajacych, Wyborcza.pl, 30.03.2019, http://wyborcza.pl/7,75517,24597816,martwisz-sie-o-kiepskie-wyniki-czytelnictwa-jestes-snobem.html [dostęp: 21.06.2019].

Zawojski P., Cyberkultura. Syntopia sztuki, nauki i technologii, Warszawa 2010. 